\title{
High frequency of vitamin D receptor gene polymorphism Fokl in Brazilian Type 1 diabetes mellitus patients with clinical autoimmune thyroid disease
}

Denise Barreto Mory, Monica Andrade Lima Gabbay*, Eloá R. Rocco, Teresa Kasamatsu, Felipe Crispim,

Walquíria Lopes Miranda and Sérgio Atala Dib

\begin{abstract}
Background: Polymorphisms of vitamin D receptor (VDR) gene have been studied as genetic markers of type 1 diabetes mellitus (T1DM) and some studies have reported associations with autoimmune thyroid disease. The aim of this study was to evaluate the relationship between VDR Fokl polymorphism (rs10735810), thyroid autoimmunity and thyroid dysfunction (TD) in Brazilian T1DM.

Methods: One-hundred-eighty T1DM patients were evaluated for age, duration of diabetes (DDM), positivity to TPO Antibody (TPOA), GAD Antibody (GADA), IA2 Antibody (IA2A) and fasting serum C-peptide (FCP) according to diagnosis of TD. PCR-RFLP analyses were carried out for VDR polymorphism Fokl.

Results: TPOA positivity ( 80.0 vs. $25.0 \%, p<0.001)$ and GADA positivity ( 56.0 vs. $30.3 \%, p=0.01$ ) were higher in T1DM patients with TD with the same age and DDM than the group without TD, with no difference of FCP and IA2A positivity. We observed higher prevalence of VDR Fokl in T1DM with TD (ff and Ff $73.9 \%$ with TD vs. $52.7 \%$ without TD, $p=0.05)$. Positivity to TPOA and presence of Fokl polymorphism were significantly associated with the concurrence of TD in T1DM patients (OR 18.1; Cl 3.7-87.0; $\mathrm{p}<0.001$ ).

Conclusions: The VDR Fokl polymorphism (rs10735810) was associated to persistence of GADA, TPOA positivity and TD in Brazilian T1DM. Positivity to TPOA and VDR polymorphism Fokl were strongly associated with concurrence of T1D and TD. These data collaborate to understanding the joint susceptibility genes for TD in T1DM.
\end{abstract}

Keywords: Type 1 diabetes, Autoimmune thyroid disease, Vitamin D receptor gene polymorphism

\section{Background}

Type 1 diabetes mellitus (T1DM) often is associated to other autoimmune diseases, and the most frequent observed is autoimmune thyroid disease (AITD) [1-4].

Fifteen to $30 \%$ of T1DM patients have autoimmune thyroid disease, as well as, $8 \%$ of their first-degree relatives, showing an increased risk for autoimmune disease. Thyroid autoimmunity is increased in females and with longer duration of diabetes [4].

*Correspondence: monicagabbay@gmail.com

Endocrinology Division, São Paulo Federal University, Rua Botucatu,

740-Vila Clementino, São Paulo, SP CEP 04034-970, Brazil
A possible explanation for the coexistence of thyroid and pancreatic autoimmunity can be found in share genetic background [5-9] and each disease is thought to be influenced by multiple susceptibility genes, as well as environmental factors [10].

Immune-modulating genes like HLA class II region gene, CTLA-4, CD40, PTNP22 and thyroid-specific genes [thyroglobulin and thyroid-stimulating hormone receptor (TSHR)] are involved in development of AITD $[10,11]$. Of these, studies showed that HLA class II genes, CTLA-4, PTNP22 and FOXP3 contribute to susceptibility to both, T1DM and AITD [7, 8, 11-13]. All of them expressed on activated CD4+ and CD8+ with a role in 
T cell activation. This observation demonstrated that the majority of the genes associated with elevated disease risk relate to the function of the immune system $[13,14]$.

Vitamin D has been recognized for its effects on the immune system [15] and polymorphisms of vitamin D receptor gene (VDR) have been studied as genetic markers of T1DM [16] and of AITD [16-22].

In healthy populations, the BsmI and TaqI bb genotype frequency was $2 \%$ among Asians, $5 \%$ among African Americans and $17 \%$ among Caucasians while the ApaI AA genotype was 9,44 and $28 \%$ respectively. [23].

The VDR FokI polymorphism in exon 2 leads to an alternative transcription initiation site resulting in a VDR protein with addition of three amino acids [24]. A functional role of this VDR polymorphism on the immune response has been previously described. It was observed in vitro that lymphocytes without VDR FokI polymorphism proliferated more strongly, with more active immune response and, monocytes and dendritic cells without polymorphism produced higher levels of IL-12 p70 protein after stimulation [25].

Despite the well-known association among T1DM, thyroid auto antibodies and clinical AITD, there have been relatively few reports on the shared genetic susceptibility for these three events $[5,6,13-22]$.

Our group had previously studied VDR gene polymorphism FokI and T1DM, and we have not observed relationship with beta cell autoimmunity. Nevertheless, T1DM individuals with this polymorphism tended to have lower residual pancreatic beta cell function when they were compared with their pairs with the same duration of disease but without the polymorphism studied [26].

The aim of the present study was to evaluate the relationship between presence of VDR gene polymorphism FokI (rs10735810), thyroid dysfunction (TD) and thyroid autoimmunity in a group of Brazilian T1DM.

\section{Methods}

\section{Study population}

We evaluated 180 patients with T1DM according to ADA criteria [27] attending the Diabetes Center of São Paulo Federal University, SP, Brazil. The study was approved by the Ethics Committee of São Paulo Federal University, Brazil (number 0814/03) and informed consent was obtained from the subjects' parents.

\section{Clinical evaluation}

Patients with T1DM from UNIFESP Diabetes Center were evaluated for age, sex, body mass index (BMI, kg/ $\mathrm{m}^{2}$ ), age at diagnosis and time from diabetes mellitus diagnosis (TDD) and diagnosis of thyroid dysfunction. In those patients with TD we also evaluated age at diagnosis and time between development of diabetes and TD. The inclusion criteria used were: patients diagnosed with type 1 diabetes, according to ADA and with the presence of thyroid antibody or TSH and/or free T4 alteration.

Exclusion criteria were: patients who presented hypothyroidism due to other causes: iodine deficiency, post thyroid ablation.

Hypothyroidism and hyperthyroidism were clinically diagnosed and confirmed according to TSH levels. Thyroid dysfunction was diagnosed in the presence of a serum TSH alteration (normal $0.5-5.0 \mathrm{mUI} / \mathrm{mL}$ ) with or without symptoms. Hypothyroidism was confirmed if TSH levels $>5.0 \mathrm{mUI} / \mathrm{mL}$ and hyperthyroidism if TSH levels were bellow $0.5 \mathrm{mUI} / \mathrm{mL}$. All patients with hypothyroidism were taking levothyroxine. Two patients with hyperthyroidism were treated with metimazol with remission of the disease after 1.5 and 1 year, and another one was still using $30 \mathrm{mg}$ daily of this drug.

We considered presence of thyroid autoimmunity positivity for thyroid peroxidase antibodies (TPOA).

\section{Biochemical analysis}

TSH was measured using an immunofluorometric assay developed in the Laboratory of Molecular Endocrinology of the Federal University of São Paulo, Brazil (normal range: $0.5-5.0 \mathrm{mUI} / \mathrm{mL}$ ). TPOA were measured by an immunofluorometric assay (autoDelfia, Turku, Finland) and we considered the reference value $<52 \mathrm{U} / \mathrm{mL}$ for the population studied. Glutamic acid decarboxylase 65 (GADA) and Insulinoma antigen-2 (IA2A) antibodies were measured by a radioimmunoassay (RSR Ltd, Cardiff, UK) and according to previous study of our group we considered the reference value $<1.72$ and $0.97 \mathrm{U} / \mathrm{mL}$ respectively [28]. Fasting serum C-peptide (FCP) was measured using an immunofluorometric assay (autoDelfia, Turku, Finland) with detection limit of $0.015 \mathrm{ng} / \mathrm{mL}$. The intra-assay variation was $4.2 \%(0.52-6.11 \mathrm{ng} / \mathrm{mL})$ and inter-assay variation of $1.1 \%(0.52 \mathrm{ng} / \mathrm{mL}), 3.4 \%$ $(6.11 \mathrm{ng} / \mathrm{mL})$. Glycated hemoglobin (HbA1c) was measured in whole blood by HPLC (TOSOH, Japan; normal range $3.5-6.0 \%$ ).

\section{Genomic DNA extraction and genotyping}

Genomic DNA was extracted from peripheral leukocytes using a commercial kit (PureGene Genome DNA Isolation Kit, Gentra Systems, Minneapolis, USA) and amplified by polymerase chain reaction (PCR). The forward primer for FokI polymorphism (rs10735810, Genbank accession no AC004466) was $5^{\prime}$ AGCTGGCCCTGGCACT GACTCTGCTCT3' and the reverse primer was $5^{\prime}$ ATGGA AACACCTTGCTTCTTCTCCCTC $3^{\prime}$. The PCR conditions for the FokI polymorphism were $94{ }^{\circ} \mathrm{C}$ for $5 \mathrm{~min}$ and 35 cycles using the following profile: $94{ }^{\circ} \mathrm{C}$ for $30 \mathrm{~s}$, 
$60{ }^{\circ} \mathrm{C}$ for $30 \mathrm{~s}$ and $72{ }^{\circ} \mathrm{C}$ for $1 \mathrm{~min}$ and a final extension at $72{ }^{\circ} \mathrm{C}$ for $10 \mathrm{~min}$. It was followed by restriction fragment length polymorphism according to previous reports for the VDR polymorphism FokI [25]. Genotypes were determined by $1.8 \%$ agarose gel electrophoresis and defined as lower case with the presence of restriction site and capital letters for its absence.

\section{Statistical analysis}

Values are expressed as mean \pm SD. Statistical analyses were performed with a SPSS for Windows version 13.0 (SPSS Inc. Chicago,Il, USA). We used Student's $t$ test, Mann-Whitney test (when variables not normally distributed) and $\chi^{2}$ tests to compare the demographics, clinical and laboratory characteristics of T1DM group according to presence or absence of TD. Logistic regression was performed in T1DM patients to assess the role of VDR FokI polymorphism in the concurrence of T1DM and TD by including the genotypes of the VDR polymorphism. $p$ values $\leq 0.05$ were considered statistically significant. Hardy-Weinberg equilibrium was calculated to evaluate the gene and genotype frequencies expected and observed.

\section{Results}

Screening for thyroid antibodies and function was performed in $180 \mathrm{~T} 1 \mathrm{DM}$ with different time of clinical diabetes diagnosis.

TPOA was positive in $32.6 \%(58 / 178)$ patients and TD was observed in $14 \%(25 / 178)$. Twenty-two patients developed primary hypothyroidism and three hyperthyroidism after mean time of T1DM diagnosis of 3 years.

TPOA positivity ( 80.0 vs. $25.0 \%, \mathrm{p}<0.001$ ) were higher in T1DM patients with TD comparing to those patients that have not developed this dysfunction. Furthermore, the female gender (72.0 vs. $48.4 \%, \mathrm{p}=0.02)$ and GADA positivity ( 56.0 vs. $30.3 \%, \mathrm{p}=0.01$ ) were also higher in T1DM patients with TD. There were no difference between groups related to age, age at diagnosis of diabetes, TDD, residual beta-cell function (FCP) and glycemic control (HbA1c).

Demographic, clinical, laboratory characteristics and prevalence of FokI polymorphism are shown according to presence or absence of TD (Table 1).

VDR polymorphism FokI genotypes frequencies were in equilibrium of Hardy-Weinberg.

We observed higher frequency of homozygosis and heterozygosis for the VDR FokI polymorphism in T1DM patients with TD comparing to those without (ff plus Ff genotypes $73.9 \%$ with TD vs. $52.7 \%$ without TD, $\mathrm{p}=0.05$; Fig. 1).

An analysis with interactive terms in a logistic regression with FokI polymorphism and positivity to TPOA
Table 1 Demographic, clinical, laboratory characteristics and prevalence of VDR Fokl polymorphism of T1DM patients according to presence or absence of thyroid dysfunction (TD)

\begin{tabular}{lllc}
\hline & With TD & Without TD & p \\
\hline $\mathrm{n}(\%)$ & $25(13.9)$ & $155(86.1)$ & \\
Gender (female \%) & 72.0 & 48.4 & 0.02 \\
Age (years) & $16.8 \pm 7.1$ & $17.1 \pm 5.0$ & 0.28 \\
Age at diagnosis of diabetes (years) & $10.0 \pm 4.0$ & $10.2 \pm 5.1$ & 0.80 \\
TDDM (years) & $6.9 \pm 6.3$ & $6.9 \pm 5.2$ & 0.72 \\
Age at diagnosis of TD (years) & $13.8 \pm 6.5$ & - & \\
BMI (kg/m ${ }^{2}$ ) & $21.3 \pm 3.2$ & $22.0 \pm 3.6$ & 0.18 \\
TSH (mUl/mL) & $19.1 \pm 59.0$ & $2.2 \pm 1.4$ & 0.00 \\
TPO Ab positive (\%) & 80.0 & 25.0 & $<0.001$ \\
GAD Ab positive (\%) & 56.0 & 30.3 & 0.01 \\
IA2 Ab positive (\%) & 36.0 & 43.1 & 0.50 \\
FCP (ng/mL) & $0.18 \pm 0.29$ & $0.19 \pm 0.42$ & 0.77 \\
A1C (\%) & $9.3 \pm 1.6$ & $9.2 \pm 1.8$ & 0.75 \\
ff/Ff genotypes (\%) & 73.9 & 52.7 & 0.05 \\
\hline
\end{tabular}

Data are expressed as mean \pm SD unless otherwise indicated

TDDM time of duration of diabetes, FCP fasting serum C-peptide

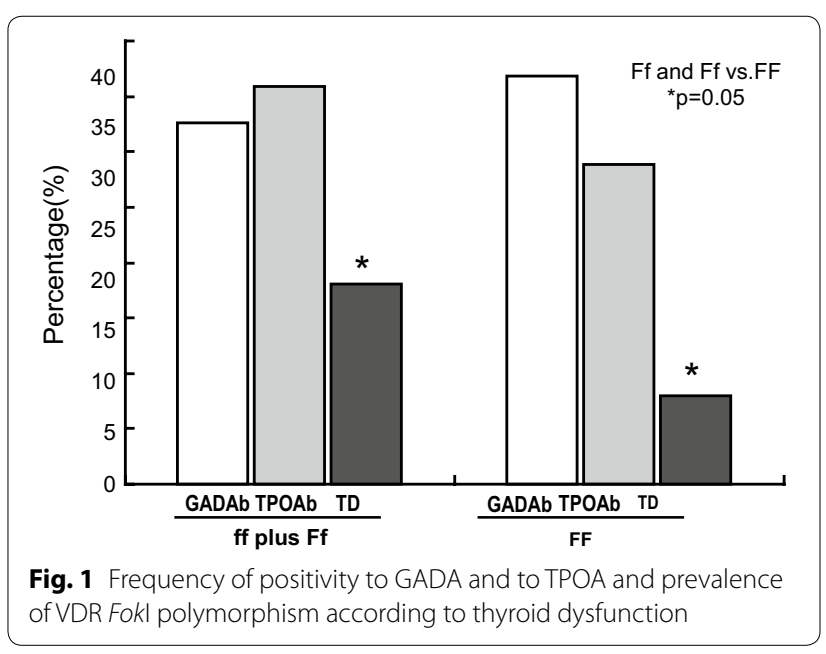

and to GADA was performed. T1DM patients with positivity to TPOA and FokI polymorphism showed 18-fold increased risk of developing TD (OR 18.1, p < 0.001; Table 2), whereas for the concurrence of GADA titers and the presence of FokI polymorphism the risk was of 8 times higher (OD 8.8, $\mathrm{p}=0.009)$.

\section{Discussion}

In a group of young T1DM patients and we found higher frequency of VDR FokI polymorphism in individuals with thyroid auto antibodies without relation to age and duration of diabetes. The titers of thyroid autoantibodies 
Table 2 ORs adjusted by logistic regression of associated variables for the association with thyroid dysfunction in T1DM

\begin{tabular}{|c|c|c|c|c|}
\hline T1DM & B & p value & OR & $95 \% \mathrm{Cl}$ \\
\hline $\begin{array}{l}\text { Without TPOAb and without } \\
\text { Fokl polymorphism }\end{array}$ & & & 1.0 & \\
\hline $\begin{array}{l}\text { Without TPOAb and with } \\
\text { Fokl polymorphism }\end{array}$ & 0.346 & 0.711 & 1.4 & $(0.2-8.8)$ \\
\hline $\begin{array}{l}\text { With TPOAb and without } \\
\text { Fokl polymorphism }\end{array}$ & 1.812 & 0.047 & 6.1 & $(1.0-36.6)$ \\
\hline $\begin{array}{l}\text { With TPOAb and with } \\
\text { Fokl polymorphism }\end{array}$ & 2.893 & $<0.001$ & 18.1 & $(3.7-87.0)$ \\
\hline $\begin{array}{l}\text { Without GADAb and without } \\
\text { Fokl polymorphism }\end{array}$ & & & 1.0 & \\
\hline $\begin{array}{l}\text { Without GADAb and with } \\
\text { Fokl polymorphism }\end{array}$ & 1.356 & 0.093 & 3.9 & $(0.8-18.9)$ \\
\hline $\begin{array}{l}\text { With GADAb and without } \\
\text { Fokl polymorphism }\end{array}$ & 1.433 & 0.114 & 4.2 & $(0.71-24.7)$ \\
\hline $\begin{array}{l}\text { With GADAb and with } \\
\text { Fokl polymorphism }\end{array}$ & 2.175 & 0.009 & 8.8 & $(1.71-45.2)$ \\
\hline
\end{tabular}

TPOAb thyroid peroxidase antibody

and GADA were higher in T1DM with TD. Positivity to TPOA and presence of FokI polymorphism were significantly associated with the concurrence of TD in T1DM patients. This is the first study that studied the association between those concomitant endocrine autoimmune diseases and VDR polymorphism in Brazilian T1DM patients.

T1DM and TD are autoimmune disease with common background. Both have the production of autoantibodies directed at the target organs (thyroid and pancreatic islets) and $\mathrm{T}$ cells-infiltration, resulting in their dysfunction and destruction. As autoimmunity progresses from initial activation to a chronic state, there is often an increase in the number of autoantigens targeted by T-cells and autoantibodies. T-cells activate additional autoreactive B-cells, and B-cells present additional epitopes from different proteins, until there is autoreactivity to diverse autoantigens [29]. Some authors consider the co-occurrence of T1DM and AITD in the same individual as one of the variants of autoimmune polyglandular syndrome type 3 (APS3s) [30].

Recent studies have evaluated shared genetic susceptibility to T1DM and Thyroid Autoimmune Disease [5-8, 12]. Nevertheless, studies with VDR polymorphisms did not evaluate individuals with these concomitant diseases [17-19]. Regarding these polymorphisms and thyroid disease distinct results have been reported. Japanese studies reported an association between VDR FokI polymorphism, Hashimoto's Thyroiditis and Graves' disease $[18,19]$. In German and Polish individuals this polymorphism was associated with Graves' disease [19], but the same was not observed in patients from United Kingdom [20] and Tunisia [21]. In the Croatian population was described an association between VDR polymorphisms haplotypes and Hashimoto's thyroiditis risk [22]. In T1DM, BsmI polymorphism has been also linked to susceptibility to present the disease in Taiwanese, Japanese, Croatians and Southern Indians [31-33].

Our finding of higher frequency of VDR FokI polymorphism in individuals with T1DM, thyroid auto antibodies and TD suggest that this polymorphism may be another loci that affect the development of both clinical diseases.

The susceptibility genes for T1DM and AITD identified to date, HLA class II, CTLA-4, PTNP22 and FOXP3 are involved in the immunological synapse and $\mathrm{T}$ cell activation [8,34]. Van Etten et al. [25] had studied in vitro the role of FokI polymorphism in autoimmunity and described that monocytes and dendritic cells without polymorphism produced higher levels of IL-12 p70 protein after stimulation. In BioBreeding rat, an animal model for AITD and diabetes, was observed an imbalance between cytokines secreted by Th1 and Th2 lymphocytes. IL- 12 mRNA expression was increased in pancreatic islets and also in thyroid gland of those diabetic animals [35]. This is the major cytokine that induces a $\mathrm{T}$ helper 1 response, resulting in $\beta$ cell destruction in T1DM [36]. Our study was not aim to evaluate the immune response but further studies are necessary to determine the relationship between cytokines, VDR polymorphism, thyroid autoimmunity and TD in T1DM patients.

In this study we observed a higher prevalence of VDR FokI polymorphism in a group of T1DM Brazilian patients with a mean of 7 years of diabetes and 3 years of TD, which presented with persistence of GADA positivity and higher prevalence of TPOA positivity. Furthermore, positivity to TPOA and presence of VDR polymorphism FokI were strongly associated with the presence of TD in T1DM patients. It was previously reported a tendency of higher frequency of thyroid auto antibodies in T1DM patients with HLA DR3/DR4 [37]. Also, a strong correlation between $\mathrm{G}$ allele of CTLA-4 gene polymorphism (rs 3087243) with TPOA was observed [38]. In Japan, two SNPs rs 2292399 in ERBB3 and rs 2903692 in CLEC16A were associated with T1DM complicated with thyroid auto antibodies [6]. Concerning VDR polymorphisms, previous studies did not evaluate the relationship with thyroid auto antibodies [17-22].

An association between positivity to GADA and TPOA had been described in T1DM patients from different populations [3, 39-41]. Moreover, it was previously described an association between PTNP22 1858T genotype and GADA positivity in a group of T1DM patients with long disease duration, suggesting that this genetic variant may help define a subgroup of patients with 
persistence of GADA [42]. A single nucleotide polymorphism (rs 3087243) of CTLA4 was associated with AITD, but not with positivity of GADA [43]. In this study we observed that positivity to GADA and presence of FokI polymorphism were significantly associated with the concurrence of TD in T1DM patients with an average of 7 years of disease.

Nevertheless, the VDR FokI polymorphism might be another susceptibility loci for thyroid autoimmunity and an additional genetic marker that in association with auto antibodies might help identifying T1DM patients with higher risk of TD.

We observed hypothyroidism in $12.2 \%$ of T1DM with a mean of 7 years of duration of diabetes, similar to observed in a prospective study that described a cumulative incidence of autoimmune thyroiditis of $14 \%$ in pediatric T1DM patients at 10 years of diagnosis [44]. The diagnosis of T1DM preceded the development of TD in this group, as previously observed by our group [45]. In addition, $72 \%$ of T1DM patients who developed TD were female and had also higher prevalence of thyroid autoimmunity, in accordance with previous studies $[1,2,38,46,47]$.

In conclusion, the present study demonstrated that the VDR FokI polymorphism (rs10735810) was associated to persistence and high titers of GADA, TPOA positivity and TD in Brazilian T1DM patients. The presence of VDR polymorphism FokI was strongly associated with concurrence of T1DM and TD in this sample population. These data collaborate to understanding the joint susceptibility genes for TD in T1DM and could potentially improve the predictive value for this disease combination development.

\begin{abstract}
Abbreviations
VDR: vitamin D receptor; TD: thyroid dysfunction; DDM: duration of diabetes; T1DM: type 1 diabetes mellitus; AITD: autoimmune thyroid disease; TPOA: thyroid peroxidase antibody; GAD A: glutamic acid decarboxylase; IA2: islet antigen 2; FCP: fasting serum C-peptide; CTLA-4: cytotoxic T-lymphocyte -associated antigen; CD40: costimulatory protein; PTNP22: protein tyrosine phosphatase; TSHR: thyroid-stimulating hormone receptor; FOXP3: forkhead box P3; TSH: thyroid stimulating hormone; PCR: polymerase chain reaction; HLA: human leukocytes antigen.
\end{abstract}

\section{Authors' contributions}

DBM, MALG, ERR participated in the design of the study and writing of the manuscript. TK, FC, WLM performed the laboratorial analysis. SAD was responsible for the study design and writing and coordination. All the authors read and approved the final manuscript.

\section{Acknowledgements}

This work was supported by Fundação de Amparo à Pesquisa do Estado de São Paulo (FAPESP). Denise B. Mory was supported by a Grant by Coordenação de Aperfeiçoamento de Pessoal de Nível Superior (CAPES).

\section{Competing interests}

The authors declare that they have no competing interests.
Received: 28 April 2015 Accepted: 10 March 2016

Published online: 22 March 2016

\section{References}

1. Perros P, McCrimmon RJ, Shaw G, Frier BM. Frequency of thyroid dysfunction in diabetic patients: value of annual screening. Diab Med. 1995;12:622-7.

2. Umpierrez GE, Latif KA, Murphy MB, Lambeth HC, Stentz F, Bush A, Kitabchi AE. Thyroid dysfunction in patients with type 1 diabetes. Diab Care. 2003:26:1181-4.

3. Barker JM, Yu J, Yu L, Wang J, Miao D, Bao F, Hoffenberg E, Nelson JC, Gottlieb PA, Rewers M, Eisenbarth G. Autoantibody "sub-specificity" in type 1 diabetes: risk for organ specific autoimmunity clusters in distinct groups. Diab Care. 2005;28:850-5.

4. Barker J. Type 1 diabetes-associated autoimmunity: natural history, genetic Associations, and screening. J Clin Endocrinol Metab. 2006:91:1210-7.

5. Pearce SHS, Merriman TR. Genetics of type 1 diabetes and autoimmune thyroid disease. Endocrinol Metab Clin N Am. 2009;38:289-301.

6. Awata T, Kawasaki E, Tanaka S, Ikegami H, Maruyama T, Shimada A, Nakanishi K, Kobayashi T, lizuka H, Uga M, Kawabata Y, Kanazawa Y, Kurihara S, Osaki M, Katayama S on behalf of the Japanese Study Group on Type 1 Diabetes Genetics. Association of type 1 diabetes with two loci on 12q13 and 16p13 and the influence coexisting thyroid autoimmunity in Japanese. J Clin Endocrinol Metab. 2009;94:231-5.

7. Levin L, Tomer Y. The etiology of autoimmune diabetes and thyroiditis: evidence for common genetic susceptibility. Autoimm Rev. 2003;2:377-86.

8. Dittmar M, Kahaly GJ. Genetics of the autoimmune polyglandular syndrome type 3 variant. Thyroid. 2010;20:737-43.

9. Jacobson EM, Tomer Y. The genetic basis of thyroid autoimmunity. Thyroid. 2007;17:949-61.

10. Golden B, Levin L, Ban Y, Concepcion E, Greenberg DA, Tomer Y. Genetic analysis of families with autoimmune diabetes and thyroiditis: evidence for common and unique genes. J Clin Endocrinol Metab. 2005;90:4904-11.

11. Dultz G, Matheis N, Dittmar M, Rohrig B, Bender K, Kahaly GJ. The protein tyrosine phosphatase non-receptor type 22 C1858T polymorphism is a joint susceptibility locus for immunethyroiditis and autoimmune diabetes. Thyroid. 2009;19:143-8.

12. Villano MJB, Huber AK, Geenberg DA, Golden BK, Concepcion E, Tomer Y. Autoimmune thyoiditis and diabetes: dissecting the joint genetic susceptibility in a large cohort of multiplex families. J Clin Endocrinol Metab. 2009;94:1458-66.

13. Tomer Y, Dolan LM, Kahaky G, Divers J, D'Agostino RB, Imperatore G, et al. Genome wide identification of new genes and pathways in patients with both autoimmune thyroiditis and type 1 diabetes. J Autoimm. 2015;60:32-9.

14. Kim EY, Shin CH, Yang SW. Polymorphisms of HLA class II predispose children and adolescents with type 1 diabetes mellitus to autoimmune thyroid disease. Autoimm. 2003;36:177-81.

15. Manolagas SC, Hustmyer FG, Yu X. Immunomodulating properties of 1,25 dihydrohyvitamin D $_{3}$. Kidney Int Suppl. 1990;29:S9-16.

16. Guo S, Magnuson VL, Schiller JJ, Wang X, Ghosh S. Meta-analysis of vitamin $D$ receptor polymorphisms and type 1 diabetes: a HuGE review of Genetic Association Studies. Am J Epidemiol. 2006;164:711-24.

17. Ban Y, Taniyama M, Ban Y. Vitamin D receptor gene polymorphisms in Hashimoto's thyroiditis. Thyroid. 2001;11:607-8.

18. Ban Y, Ban Y, Taniyama M, Katagiri T. Vitamin D receptor initiation codon polymorphism in Japanese patients with Graves' disease. Thyroid. 2000;10:475-80.

19. Ramos-Lopez E, Kurylowicz A, Bednarczuk T, Paunkovic J, Seidl C, Badenhoop K. Vitamin D receptor polymorphisms are associated with Graves' disease in German and Polish but not in Serbian patients. Thyroid. 2005;15:1125-30. 
20. Collins JE, Heward JM, Nithiyananthan R, Nejentsev S, Todd JA, Franklyn JA, Gough SCL. Lack of association of the vitamin D receptor gene with Graves' disease in UK Caucasians. Clin Endocrinol (Oxf). 2004;60:618-24.

21. Maalej A, Petit-Teixeira E, Chabchoub G, Hamad BM, Rebai A, Farid NR, Cornelis F, Ayadi H. Lack of association of VDR gene polymorphisms with thyroid autoimmune disorders: familial and case/control Studies. J Clin Immunol. 2008;28:21-5

22. Stefanic M, Papic S, Suver M, Glavas-Obrovac L, Karner I. Association of vitamin D receptor gene 3 '- variants with Hashimoto's thyroiditis in the Croatian population. Int J Immunogenet. 2008;35:125-31.

23. Zmuda J, Cauley JA, Ferrell RE. Molecular epidemiology of vitamin D receptor gene variants. Epidemiol Rev. 2000;22:203-17.

24. Miyamoto K, Kesterson RA, Yamamoto H, Taketani Y, Nishiwaki E, Tatsum S, Inoue Y, Morita K, Takeda E, Pike JW. Structural organization of the human vitamin D receptor chromosomal gene and its promoter. Mol Endocrinol. 1997;11:1165-79.

25. van Etten E, Verliden L, Giulietti A, Ramos-Lopez E, Branisteanu DD, Ferreira GB, Overbergh L, Verstuyf A, Bouillon R, Roep BO, Badenhoop K, Mathieu C. The vitamin D receptor gene Fokl polymorphism: functional impact on the immune system. Eur J Immunol. 2007;37:395-405.

26. Mory DB, Rocco ER, Miranda WL, Kasamatsu T, Crispim F. Dib SA prevalence of vitamin D receptor gene polymorphisms Fokl and Bsml in Brazilian individuals with type 1 diabetes and their relationship to $\beta$-cell autoimmunity and to remaining $\beta$-cell function. Hum Immunol. 2009;70:447-51.

27. Expert Committe on the Diagnosis and Classification of Diabetes Mellitus. Report of the expert committe on the diagnosis and classification of diabetes mellitus. Diab Care. 2014;37(Supl 1):S81-90.

28. Cesarini PR, Mendonça E, Fernandes V, do Silva RC, Morimitsu LK, Garcia FE, Vechiatti S, Miranda WL, Dib SA. Prevalence of immunological markers (anti-GAD and anti-IA2) in first-degree relatives of patients of type 1 diabetes in the greater area of São Paulo. Rev assoc Med Bras. 2003:49:395-400

29. Pietropaolo M, Barinas-Mitchell E, Kuller LH. The heterogeneity of diabetes. unraveling a dispute: is systemic inflammation related to islet autoimmunity? Diabetes. 2007;56:1189-97.

30. Eisenbarth GS, Gottlieb PA. Autoimmune polyendocrine syndromes. N Engl J Med. 2004;350:2068-79.

31. Valdivieso JM, Fernandez E. Vitamin D receptor polymorphisms and diseases. Clin Chin Acta. 2006;371:1-12.

32. Chang T-J, Lei H-H, Yeh J-I, Chiu KC, Lee K-C, Chen M-C, Tai T-Y, Chuang L-M. Vitamin D receptor gene polymorphisms influence susceptibility to type 1 diabetes mellitus in the Taiwanese population. Clin Endocrinol (Oxf). 2000:52:575-80

33. Ban Y, Taniyama T, Yamada S, Maruyama T, Kasuga A, Ban Y. Vitamin D receptor iniciation codon polymorphism influences genetic susceptibility to type 1 diabetes in the Japanese Population. BMC Med Genet. 2001;2:7.

34. Tomer Y, Meconi F. Type 1 diabetes and autoimmune thyroiditis: the genetic connection. Thyroid. 2009;19:99-102.
35. Zipris D. Evidence that Th1 lymphocytes predominate in islet inflammation and thyroiditis in the BioBreeding (BB) rat. J Autoimmun. 1996:9:315-9

36. Kukreja A, Maclaren NK. Autoimmunity and diabetes. J Clin Endocrino Metab. 1999:84:4371-8

37. Holl RW, Bohm B, Loos U, Grabert M, Heinze E, Homoki J. Thyroid autoimmunity in children and adolescents with type 1 diabetes mellitus. Effect of age, gender and HLA type. Horm Res. 1999;52:113-8.

38. Howson JMM, Dunger DB, Nutland S, Stevens H, Wicker LS, Todd JA. A type 1 diabetes subgroup with a female bias is characterised by failure in tolerance to thyroid peroxidase at an early age and a strong association with the cytotoxic T-lymphocyte-associated antigen-4 gene. Diabetologia. 2007;50:741-6.

39. Fernández-Castañer M, Molina A, López-Jiménez L, Gómez JM, Soler J. Clinical presentation and early course of type 1 diabetes in patients with and without thyroid autoimmunity. Diab Care. 1999;22:377-81.

40. Rattarasarn C, Diosdado MA, Ortego J, Leelawattana R, Soonthornpun S, Setasuban W, Jaruratanasirikul S, Patarakijvanich N. Thyroid autoantibodies in Thai type 1 diabetic patients: clinical significance and their relationship with glutamic acid decarboxylase antibodies. Diab Res Clin Pract. 2000;49:107-11.

41. Bárová H, Perusicová J, Hill M, Sterzl I, Vondra K, Masek Z. Anti-GADpositive patients with type 1 diabetes mellitus have higher prevalence of autoimmune thyroiditis than anti-GAD-negative patients with type 1 and type 2 diabetes mellitus. Physiol Res. 2004;53:279-86.

42. Chelala C, Duchatelet S, Joffret M-L, Bergholdt R, Dubois-Laforgue D, Ghandil P, Pociot F, Caillat-Zucman S, Timsit J, Julier C. PTNP22 R620W functional variant in type 1 diabetes and autoimmunity related traits. Diabetes. 2007;56:522-6.

43. Moriguchi M, Noso S, Kawanata Y, Yamauchi T, Harada T, Komaki K, Babaya Y, Hirome Y, Ito H, Yamagata S, Murata K, Higashimoto T, Park C, Yamamoto S, Ohno Y, Ikegami H. Clinical and genetic characteristics of patients with autoimmune thyroid disease with anti-islet autoimmunity. Metabolism. 2011;60:761-6.

44. Kordounori O, Hartmann R, Deiss D, Wilms M, Gruters-Kieslich A. Natural course of autoimmune thyroiditis in type 1 diabetes: association to gender, age, diabetes duration and puberty. Arch Dis Child. 2005;90:411-4.

45. Silva RC, Monteagudo PT, Dib SA. Relação cronológica entre o Aparecimento do Diabetes Melitus do Tipo I e das Tiroidopatias nas Síndromes Poliglandulares Auto- Imunes (SPAs). Arq Bras Endocrinol Metabol. 1996;40:180-6.

46. Kourdonouri O, Klinghammer A, Lang EB, Gruters-Kieslich A, Grabert M, Holl RW. Thyroid autoimmunity in children and adolescents with type 1 diabetes. Diab Care. 2002;25:1346-50.

47. Araujo J, Brandão LA, Guimarães RL, Santos S, Falcão EA, Milanese M, Segat L, Souza PR, de Lima-Filho JL, Crovella S. Prevalence of autoimmune thyroid disease and thyroid dysfunction in young Brazilian patients with type 1 diabetes. Pediatr Diab. 2008;9:272-6.

\section{Submit your next manuscript to BioMed Central and we will help you at every step:}

- We accept pre-submission inquiries

- Our selector tool helps you to find the most relevant journal

- We provide round the clock customer support

- Convenient online submission

- Thorough peer review

- Inclusion in PubMed and all major indexing services

- Maximum visibility for your research

Submit your manuscript at www.biomedcentral.com/submit
() Biomed Central 